\title{
ASURANSI SYARIAH DAN GAGASAN AMANDEMEN UNDANG-UNDANG NOMOR 02 TAHUN 1992 TENTANG PERASURANSIAN
}

\author{
Hidayatulloh \\ Fakultas Syariah dan Hukum Universitas Islam Negeri Syarif Hidayatullah \\ E-mail: dayatfsh@yahoo.co.id
}

\begin{abstract}
Saria Insurance has been present since 1994 with the birth of PT Syarikat Takaful Indonesia, which then established PT Asuransi Takaful Family (Life Insurance) and PT Asuransi Takaful Umum (General Insurance). That is, already 18 years Saria Insurance live, thrive and exist in the midst of the people of Indonesia. In contrast to his siblings, Islamic banking, which has had legal certainty with the Law Number 21 of 2008 concerning Islamic Banking, Islamic insurance not specifically regulated in the rule of law. Though true, Islamic principles should be applied, and Law Number 2 of 1992 on the Insurance have not been able to accommodate all the principles of sharia Islamic insurance industry in Indonesia. The presence of legislation on Islamic insurance, either by making special laws or amendments to laws existing insurance, are great expectations in order to ensure legal certainty for stakeholders and provide confidence to the public in using the products and services of Islamic insurance.
\end{abstract}

Keywords: Islamic Insurance, Insurance Act, Amendment, Rule of Law.

\begin{abstract}
abstrak
Asuransi syariah telah hadir sejak tahun 1994 dengan lahirnya PT Syarikat Takaful Indonesia, yang kemudian mendirikan PT Asuransi Takaful Keluarga (Life Insurance) dan PT Asuransi Takaful Umum (General Insurance). Artinya, sudah 18 tahun asuransi syariah hidup, berkembang, dan eksis di tengah-tengah masyarakat Indonesia. Berbeda dengan saudara kandungnya, perbankan syariah, yang telah memiliki kepastian hukum dengan adanya Undang-Undang Nomor 21 Tahun 2008 tentang Perbankan Syariah, asuransi syariah belum diatur secara khusus dalam aturan perundang-undangan. Padahal sejatinya, prinsip-prinsip syariah harus diaplikasikan, dan Undang-Undang Nomor 2 Tahun 1992 tentang Perasuransian belum mampu mengakomodir seluruh prinsip-prinsip syariah bagi industri asuransi syariah di Indonesia. Hadirnya peraturan perundangundangan tentang asuransi syariah, baik dengan membuat undang-undang khusus ataupun amandemen undang-undang perasuransian yang ada, adalah harapan besar guna menjamin kepastian hukum bagi stakeholders dan
\end{abstract}


sekaligus memberikan keyakinan kepada masyarakat dalam menggunakan produk dan jasa asuransi syariah.

Kata kunci: Asuransi Syariah, Undang-Undang Perasuransian, Amandemen, Kepastian Hukum.

\section{A. Pendahuluan}

Perkembangan ekonomi, dalam kaitannya dengan industri dan bisnis, berjalan dengan cepat seiring dengan perkembangan kehidupan manusia yang terbantu oleh kemajuan ilmu pengetahuan dan teknologi. Setiap individu atau pun kelompok manusia, baik kelompok kecil hingga dalam ikatan sebuah bangsa, ingin meningkatkan taraf kehidupan dengan meningkatkan kualitas perekonomiannya.

Islam, sebagai agama rahmatan lil 'alamin, tentunya sangat merespon akan kebutuhan manusia untuk meningkatkan taraf kehidupannya dengan menjalankan bisnis dan mengembangkan industri kreatif dalam menggapai kesejahteraan dan kemakmuran. Syariat Islam memberikan celah yang sangat luas dalam aspek kegiatan ekonomi, atau disebut muamalat. Dalam kaidah fikih disebutkan bahwa "Pada dasarnya, semua bentuk muamalah boleh dilakukan kecuali ada dalil yang mengharamkannya". ${ }^{.}$

Salah satu aspek muamalat yang berkembang di tengah-tengah masyarakat modern saat ini, dalam hal ini di Indonesia, adalah asuransi syariah. Asuransi syariah (ta'min, takaful, dan tadhamun) adalah usaha saling melindungi dan tolong-menolong di antara sejumlah orang/pihak melalui investasi dalam bentuk aset dan/atau tabarru' yang memberikan pola pengembalian untuk menghadapi risiko tertentu melalui akad (perikatan) yang sesuai dengan syariah. ${ }^{2}$

Akan tetapi cukup disayangkan, keberadaan industri asuransi syariah belum disentuh oleh aturan hukum yang akomodatif terhadap kepastian hukumnya. Tulisan ini akan memaparkan asuransi syariah, dari mulai sejarah dan perkembangannya, prinsip-prinsipnya, akad dan produk yang ditawarkan, dan landasan hukumnya. Kemudian dari tulisan ini akan terlihat bahwa kebutuhan akan aturan hukum, dengan amandemen undang-undang perasuransian yang berlaku saat ini, adalah sebuah kebutuhan yang

\footnotetext{
${ }^{1}$ Kaidah ini merupakan kaidah dasar dalam muamalat dan menunjukan keluwesan syariat Islam dalam hubungan antar manusia. Kaidah ini banyak dibahas dalam literatur kaidah fikih, antara lain oleh Abu 'Abd al-Rahman 'Abd al-Majid al-Jazairi, al-Qawaid alFiqhiyyah: al-Mustakhrajat min Kitab I'lam al-Muwaqqi'in. (Beirut: Dar Ibnu Qayyim dan Dar Ibnu 'Affan, t.t.), hlm. 542.

2 Fatwa Dewan Syariah Nasional No. 21/DSN-MUI/X/2001 tentang Pedoman Umum Asuransi Syariah.
} 
mendesak (emergency need) yang sebaiknya segera untuk dilakukan oleh para pembuat undang-undang di Negara Kesatuan Republik Indonesia.

\section{B. Pembahasan}

\section{Sejarah dan Perkembangan Asuransi Syariah di Indonesia}

Asuransi, sebagai salah satu lembaga keuangan yang bergerak dalam bidang pertanggungan, merupakan sebuah institusi modern hasil temuan dari dunia Barat, yang lahir bersamaan dengan adanya semangat pencerahan (reinaissance). Institusi ini, bersama dengan lembaga keuangan bank, menjadi motor penggerak ekonomi pada era modern dan berlanjut pada masa sekarang. Dasar yang menjadikan semangat operasional asuransi modern adalah berorientasikan pada sistem kapitalis yang intinya hanya bermain dalam pengumpulan modal untuk keperluan pribadi atau golongan tertentu. ${ }^{3}$

Lain halnya dengan asuransi syariah. Asuransi yang lahir dari literatur keislaman, lebih banyak bernuansa sosial daripada bernuansa ekonomi atau profit oriented (keuntungan bisnis). Hal ini dikarenakan oleh aspek tolongmenolong yang menjadi dasar utama dalam menegakan praktek asuransi dalam Islam. Maka, tatkala konsep asuransi tersebut dikemas dalam sebuah organisasi perusahaan yang berorientasi kepada profit, akan berakibat pada penggabungan dua visi yang berbeda, yaitu visi sosial, sebagai landasan utama, dan visi ekonomi, sebagai landasan periferal. ${ }^{4}$ Oleh karena itu, penggabungan kedua visi tersebut merupakan salah satu keunggulan dari asuransi yang bersumber dari ajaran Islam.

Asuransi syariah di Indonesia lahir pertama kali dengan berdirinya Asuransi Takaful Indonesia pada tanggal 25 Agustus 1994 melalui Surat Keputusan Menteri Keuangan No. Kep-385/KMK.017/1994. Pendirian Asuransi Takaful Indonesia diprakarsai oleh Tim Pembentuk Asuransi Takaful Indonesia (TEPATI) yang dipelopori oleh Ikatan Cendekiawan Muslim Indonesia (ICMI) melalui Yayasan Abdi Bangsa, Bank Muamalat Indonesia, Asuransi Jiwa Tugu Mandiri, Pejabat dari Departemen Keuangan, dan Pengusaha Muslim Indonesia. ${ }^{5}$

Cikal bakal berdirinya Asuransi Takaful Indonesia adalah hasil berbagai seminar nasional dan setelah mengadakan studi banding dengan Takaful Malaysia. Setelah itu berdirilah PT Syarikat Takaful Indonesia (PT

\footnotetext{
${ }^{3}$ Sistem kapitalis memiliki karakteristik antara lain: kepemilikan pribadi dalam produksi, pasar bebas, mencari keuntungan sebagai tujuan utama dalam kegiatan ekonomi, dan seterusnya. Lihat Maxime Rodinson, Islam and Capitalism. (Austin: University of Texas Press, 1978), hlm. 4.

${ }^{4}$ AM. Hasan Ali, Asuransi dalam Perspektif Hukum Islam: Suatu Tinjauan Analisis Historis, Teoritis, dan Praktis. (Jakarta: Kencana Prenada Media, 2004), hlm. 25.

${ }^{5}$ Training \& Development Department PT Asuransi Takaful Keluarga, Modul Basic Training 2002. (Jakarta: PT Asuransi Takaful Keluarga, 2002), hlm. 2.
} 
STI) sebagai Holding Company pada tanggal 24 Februari 1994. Kemudian PT STI mendirikan dua anak perusahaan, yakni PT Asuransi Takaful Keluarga (Life Insurance) dan PT Asuransi Takaful Umum (General Insurance). PT Asuransi Takaful Keluarga diresmikan lebih awal pada tanggal 24 Agustus 1994 oleh Bapak Mar'ie Muhammad selaku Menteri Keuangan saat itu setelah mendapatkan izin operasional pada tanggal 4 Agustus $1994 .^{6}$

Setelah itu, beberapa perusahaan asuransi syariah yang lain mencoba untuk bersaing. Menurut survei dari Karim Business Consulting (KBC), potensi pasar asuransi syariah di Indonesia, setidak-tidaknya dapat digolongkan menjadi tiga kelompok potensial. Pertama, mereka yang menghendaki agar transaksi asuransinya benar-benar memiliki orientasi syariah. Jumlahnya tidak terlau besar, mengingat kesadaran terhadap produk-produk asuransi bernilai syariah masih belum signifikan. Kedua, mereka yang potensial untuk melakukan perpindahan (switching) dari satu model asuransi ke model lainnya. Mereka ini lebih menginginkan profit dan benefit ketimbang nilai syariahnya. Jumlahnya sangat dominan dan umumnya berasal dari kelas menengah. Ketiga, mereka yang selama ini setia kepada suatu model asuransi konvensional dan sukar untuk berpindah ke model lain, karena sudah merasa comfort dan percaya. Satu-satunya persyaratan mereka untuk melakukan perpindahan (switching) adalah apabila kualitas model asuransi tersebut sama atau lebih dari model yang selama ini mereka preferensikan. ${ }^{7}$

Perkembangan industri asuransi syariah berkembang pesat. Jumlah lembaga asuransi syariah, baik yang murni menjalankan prinsip syariah maupun yang menjadikan asuransi syariah sebagai alternatif produk yang ditawarkan, berjumlah 49 perusahaan, 3 reasuransi, dan 7 broker asuransi dan reasuransi. Data ini berdasarkan sumber Dewan Syariah Nasional (DSN) Majelis Ulama Indonesia. ${ }^{8}$ (Lihat tabel 1)

\footnotetext{
${ }^{6}$ Ibid, hlm. 20.

7 Adiwarman Karim, 12 Perusahaan Asuransi Syariah akan Beroperasi. Republika edisi Jumat, 07 Maret 2003.

${ }^{8}$ M. Ichwan Sam, dk. (ed.), Tanya Jawab Seputar Dewan Syariah Nasional Majelis Ulama Indonesia. (Jakarta: Sekretariat DSN-MUI, 2011), hlm. 36.
} 


\section{Table 1}

\section{Daftar Asuransi, Reasuransi, dan Broker Syariah}

\begin{tabular}{|l|l|}
\hline I. & Asuransi Syariah \\
\hline 1. & PT Asuransi Takaful Umum \\
\hline 2. & PT Asuransi Takaful Keluarga \\
\hline 3. & PT Asuransi Syariah Mubarakah \\
\hline 4. & PT MAA Life Assurance \\
\hline 5. & PT MAA General Assurance \\
\hline 6. & PT Great Eastern Life Indonesia \\
\hline 7. & PT Asuransi Tri Pakarta \\
\hline 8. & PT AJB Bumiputera 1912 \\
\hline 9. & PT Asuransi Jiwa BRIngin Life Sejahtera \\
\hline 10. & PT Asuransi BRIngin Sejahtera Artamakmur \\
\hline 11. & PT Asuransi Jasindo Takaful \\
\hline 12. & PT Asuransi Central Asia \\
\hline 13. & PT Asuransi Umum Bumi Putera Muda 1967 \\
\hline 14. & PT Asuransi Astra Buana \\
\hline 15. & PT BNI Life Insurance \\
\hline 16. & PT Asuransi Adira Dinamika \\
\hline 17. & PT Staco Jasapratama \\
\hline 18. & PT Asuransi Sinar Mas \\
\hline 19. & PT Asuransi Tokio Marine Indonesia \\
\hline 20. & PT Asuransi Jiwa Sinar Mas \\
\hline 21. & PT Tugu Pratama Indonesia \\
\hline 22. & PT Avrist Assurance \\
\hline 23. & PT Asuransi Allianz Life Indonesia \\
\hline 24. & PT Panin Life \\
\hline 25. & PT Asuransi Allianz Utama Indonesia \\
\hline 26. & PT Asuransi Ramayana, Tbk \\
\hline 27. & PT Asuransi Jiwa Mega Life \\
\hline 28. & PT AJ Central Asia Raya \\
\hline 29. & PT Asuransi Parolamas \\
\hline 30. & PT Asuransi Umum Mega \\
\hline 31. & PT Asuransi Jiwa Askrida \\
\hline 32. & PT Asuransi Jiwasraya (Persero) \\
\hline 33. & PT Equity Life Indonesia \\
\hline 34. & PT Asuransi Kredit Indonesia (Askrindo) \\
\hline 35. & PT Asuransi Bintang, Tbk \\
\hline 36. & PT Asuransi Bangun Askrida \\
\hline 37. & PT Prudential Life Assurance \\
\hline & \\
\hline
\end{tabular}




\begin{tabular}{|l|l|}
\hline 38. & PT Jasaraharja Putera \\
\hline 39. & PT AIA Financial \\
\hline 40. & PT Asuransi Jiwa Sequis Life \\
\hline 41. & PT Sun Life Financial Indonesia \\
\hline 42. & PT AXA Services Indonesia \\
\hline 43. & PT Chartis Insurance Indonesia \\
\hline 44. & PT Asuransi Jiwa Manulife Indonesia \\
\hline 45. & PT Anugrah Life \\
\hline 46. & PT Asuransi Syariah Duta Future International \\
\hline 47. & PT Jaya Proteksi Takaful \\
\hline 48. & PT Asuransi Jiwa Syariah Al-Amin \\
\hline 49. & PT Asuransi Ekspor Indonesia (Persero) \\
\hline
\end{tabular}

\begin{tabular}{|c|l|}
\hline II. & Reasuransi Syariah \\
\hline 1. & PT Reasuransi Internasional Indonesia (Reindo) \\
\hline 2. & PT Reasuransi Nasional Indonesia (Nasre) \\
\hline 3. & PT Maskapai Reasuransi Indonesia (Marein) \\
\hline
\end{tabular}

\begin{tabular}{|c|l|}
\hline III. & Broker Asuransi dan Reasuransi \\
\hline 1. & PT Fresnel Perdana Mandiri \\
\hline 2. & PT Asiare Binajasa \\
\hline 3. & PT Amanah Jamin Indonesia \\
\hline 4. & PT Asrinda Re-Brokers dan AA Pialang Asuransi \\
\hline 5. & PT Madani Karsa Mandiri \\
\hline 6. & PT Aon Indonesia \\
\hline 7. & PT Visi Bersama Serantau \\
\hline
\end{tabular}

\section{Prinsip-Prinsip Dasar Asuransi Syariah}

Sebuah bangunan hukum akan tegak secara kokoh, jika dibangun atas pondasi dan dasar yang kuat. Ibarat sebuah rumah, jika dibangun dengan pondasi yang rapuh, cepat atau lambat rumah itu akan mengalami kehancuran dan roboh diterpa badai. Sebaliknya, bangunan rumah yang didasari dengan pondasi yang kuat akan menghasilkan sebuah rumah yang kokoh dan tahan terhadap badai.

Prinsip dasar yang ada dalam asuransi syariah tidak jauh berbeda dengan prinsip dasar yang berlaku pada konsep ekonomi Islam secara komprehensif dan bersifat major. Hal ini disebabkan karena kajian asuransi syariah merupakan turunan (minor) dari konsep ekonomi Islam. Menurut AM. Hasan Ali, prinsip-prinsip dasar asuransi syariah ada sepuluh, yaitu: 
tauhid, keadilan, tolong-menolong, kerja sama, amanah, kerelaan, kebenaran, larangan riba, larangan judi, dan larangan gharar. ${ }^{9}$

Tidak jauh berbeda, Muhammad Syakir Sula mengemukakan prinsipprinsip muamalah yang melandasi asuransi syariah adalah tauhid (ketakwaan), al-'adl (sikap adil), menjauhi al-zulm (kezaliman), al-ta'awun (tolong-menolong), al-amanah (terpercaya/jujur), ridha (suka sama suka), menghindari riswah (sogok/suap), al-maslahah (kemaslahatan), al-khidmah (pelayanan), larangan berbuat al-tathfif (kecurangan), dan mengeliminir unsur gharar, maisir, dan riba. ${ }^{10}$

Sedangkan para pakar ekonomi Islam, sebagaimana dikutip oleh Gemala Dewi, mengemukakan bahwa asuransi syariah ditegakan atas tiga prinsip utama, yaitu ${ }^{11}$ :

a. saling bertanggung jawab, yang berarti para peserta asuransi memiliki rasa tanggung jawab bersama membantu dan menolong peserta lain yang mengalami musibah atau kerugian dengan niat ikhlas;

b. saling bekerja sama atau saling membantu, yang berarti di antara peserta asuransi takaful yang satu dengan lainnya saling bekerja sama dan saling tolong-menolong dalam mengatasi kesulitan yang dialami karena sebab musibah yang diderita; dan

c. saling melindungi penderitaan satu sama lain, yang berarti bahwa para peserta asuransi takaful akan berperan sebagai pelindung bagi peserta lain yang mengalami gangguan keselamatan berupa musibah yang dideritanya.

Dari ketiga prinsip utama di atas, Karnaen A. Perwataatmadja menambahkan satu prinsip lagi sebagai tambahan, yakni menghindari unsur gharar, maisir, dan riba. Menurutnya ketiga unsur tersebut harus dihindari dari transaksi ekonomi Islam. ${ }^{12}$

Muhammad Syafi'i Antonio memberikan ilustrasi yang sederhana tapi jelas dalam menjelaskan masalah gharar. Dalam konsep syariah, masalah gharar dapat dieliminir karena akad yang dipakai bukanlah aqd tabaduli,

${ }^{9}$ AM. Hasan Ali, Asuransi dalam Perspektif Hukum Islam..., hlm. 125.

10 Muhammad Syakir Sula, Asuransi Syariah (Life and General): Konsep dan Sistem Operasional. (Jakarta: Gema Insani Press, 2004), hlm. 722.

11 Gemala Dewi, Aspek-aspek Hukum dalam Perbankan dan Perasuransian Syariah di Indonesia. (Jakarta: Kencana Prenada Media, 2007), hlm. 146. Lihat pula Gemala Dewi, dk., Hukum Perikatan Islam di Indonesia. (Jakarta: Kencana Prenada Media, 2007), hlm. 166.

${ }^{12}$ Gharar adalah ketidakpastian (uncertainty), baik dalam bentuk akad maupun sumber dana pembayaran klaim. Maisir (gambling, pertaruhan) artinya ada salah satu pihak yang untung namun di lain pihak justru mengalami kerugian. Unsur riba tercermin dalam melakukan usaha dan investasi di mana meminjamkan dana premi yang terkumpul atas dasar bunga. Lihat Karnaen A. Perwataatmadja, Membumikan Ekonomi Islam di Indonesia. (Depok: Usaha Kami, 1996), hlm. 234. Lihat juga Gemala Dewi, Aspek-aspek Hukum dalam Perbankan dan Perasuransian Syariah di Indonesia..., hlm. 149. 
tetapi aqd takafuli atau tolong-menolong dan saling menjamin. Adapun masalah maisir, asuransi syariah telah mengubah akadnya dan membagi dana peserta ke dalam dua rekening (pada produk life yang mengandung unsur tabungan). Karena rekening khusus yang menampung dana tabarru' yang ada tidak bercampur dengan rekening peserta, maka reversing period diasuransi syariah terjadi sejak awal. Kapan saja peserta dapat mengambil uangnya (karena pada hakikatnya itu adalah uang mereka sendiri), dan nilai tunai sudah ada sejak awal tahun pertama ia masuk. Karena itu, tidak ada maisir, tidak ada gambling, karena tidak ada pihak yang dirugikan. Sedangkan masalah riba dieliminir dengan konsep mudharabah (bagi hasil). ${ }^{13}$

\section{Akad dan Produk Asuransi Syariah}

Akad secara bahasa berarti al-ribthu atau ikatan yang menggabungkan antara dua pihak. Yang dimaksud ikatan di sini adalah ikatan secara hissi (nyata) atau pun secara ma'nawi (makna) saja. Adapun pengertian akad secara istilah terbagi menjadi dua, 'amm (general) dan khash (specific). Makna 'amm adalah lebih dekat kepada pengertian secara bahasa, yaitu segala sesuatu yang dikehendaki oleh seseorang untuk melakukan perbuatan, baik secara individu seperti wakaf, dan sebagainya, dan secara bersama seperti jual beli, sewa-menyewa, dan sebagainya. Sedangkan makna khash, sebagaimana yang dikemukakan oleh Al-Syanhuri dan dikutip oleh Wahbah al-Zuhaili, adalah "kesepakatan antara dua kehendak untuk membangun kewajiban atau memindahkan kewajiban atau dengan mengakhiri kewajiban". ${ }^{14}$ Adapun akad yang berkaitan dengan transaksi dalam asuransi syariah adalah akad yang bermakna khash.

Adapun akad yang ada dalam praktek asuransi syariah adalah akad tabarru' dan akad mudharabah. Pertama, akad tabarru' dalam konteks asuransi syariah bertujuan memberikan dana kebajikan dengan niat ikhlas untuk tujuan saling membantu di antara sesama peserta, apabila ada diantaranya yang dapat musibah. Dana klaim yang diberikan, diambil dari rekening dana tabarru' yang sudah diniatkan oleh semua peserta ketika akan menjadi peserta asuransi syariah, digunakan untuk kepentingan dana kebajikan atau dana tolong-menolong. ${ }^{15}$ Akad tabarru' terkumpul dalam rekening dana sosial yang tujuan utamanya digunakan untuk saling menanggung (takaful) peserta asuransi yang mengalami musibah kerugian. ${ }^{16}$

\footnotetext{
${ }^{13}$ Muhammad Syafi'i Antonio, Asuransi dalam Perspektif Islam. (Jakarta: Syarikat Takaful Indonesia, 1994), hlm. 2.

${ }^{14}$ Selengkapnya lihat Wahbah al-Zuhaili, al-Fiqh al-Islami wa Adillatuh. (Beirut: Dar al-Fikr, 1985), juz 4, hlm. 80.

${ }^{15}$ Muhammad Syakir Sula, Asuransi Syariah (Life and General)..., hlm. 36.

${ }^{16}$ AM. Hasan Ali, Asuransi dalam Perspektif Hukum Islam..., hlm. 141.
} 
Kedua, akad mudharabah. Akad ini terwujud tatkala dana yang terkumpul dalam perusahaan asuransi itu diinvestasikan dalam wujud usaha yang diproyeksikan menghasilkan keuntungan (profit). Karena landasan dasar awal dari akad mudharabah ini adalah prinsip profit and loss sharing, jika dalam investasinya mendapat keuntungan, maka keuntungan tersebut dibagi bersama sesuai dengan porsi (nisbah) yang disepakati. Sebaliknya, jika dalam investasinya mengalami kerugian (loss atau negative return), maka kerugian tersebut juga ditanggung bersama antara peserta asuransi dan perusahaan. $^{17}$

Asuransi syariah, berkaitan dengan produk-produknya, tidak jauh berbeda dengan asuransi konvensional dalam mendesain produk-produknya. Meskipun demikian, perbedaan yang ada di antara keduanya adalah berkaitan dengan akad, prinsip dalam investasi dana, kepemilikan dana, pembayaran klaim, dan keuntungan investasi. ${ }^{18}$

Produk-produk asuransi syariah, secara garis besar, terbagi dua, yaitu: takaful keluarga (asuransi jiwa) dan takaful umum (asuransi kerugian). Takaful keluarga adalah bentuk asuransi syariah yang memberikan perlindungan dalam menghadapi musibah kematian dan kecelakaan atas diri peserta asuransi takaful. Produk takaful keluarga meliputi: takaful berencana, takaful pembiayaan, takaful pendidikan, takaful dana haji, takaful berjangka, tabungan kecelakaan siswa, takaful kecelakaan diri, dan takaful khairat keluarga. ${ }^{19}$

Sedangkan takaful umum adalah bentuk asuransi syariah yang memberikan perlindungan finansial dalam menghadapi bencana atau kecelakaan atas harta benda milik peserta takaful, seperti rumah, bangunan, dan sebagainya. Produk takaful umum meliputi: takaful kendaraan bermotor, takaful kebakaran, takaful kecelakaan diri, takaful pengangkutan laut, takaful rekayasa/engineering, dan lain-lain. ${ }^{20}$

\section{Landasan Hukum Asuransi Syariah}

Landasan hukum asuransi syariah adalah berdasarkan sumber hukum yang bersifat otoritatif. Dalam hal ini, kami membagi landasan hukumnya

\footnotetext{
${ }^{17}$ AM. Hasan Ali, Asuransi dalam Perspektif Hukum Islam..., hlm. 141. Bandingkan dengan konsep profit and loss sharing dalam perbankan syariah. lihat Adiwarman A. Karim, Bank Islam: Analisis Fiqih dan Keuangan. (Jakarta: RajaGrafindo Persada, 2011), hlm. 210.

18 Gemala Dewi, Aspek-aspek Hukum dalam Perbankan dan Perasuransian Syariah di Indonesia..., hlm. 152

${ }^{19}$ Muhammad Syafi'i Antonio, Prinsip Dasar Operasi Asuransi Takaful dalam Arbitrase Islam di Indonesia. (Jakarta: Badan Arbitrase Muamalat Indonesia, 1994), hlm. 150.

20 Muhammad Syafi'i Antonio, Prinsip Dasar Operasi Asuransi Takaful..., hlm. 151. Bandingkan dengan Muhammad Syakir Sula, Asuransi Syariah (Life and General)..., hlm. 636.
} 
menjadi dua bagian, yaitu: landasan hukum yang bersumber dari sumber hukum Islam dan landasan hukum yang bersumber dari peraturan perundang-undangan di Indonesia.

Berkaitan dengan landasan hukum Islam mengenai asuransi syariah, kita dapat merujuk kepada dalil-dalil syariat, baik yang disepakati, yakni alQuran dan al-Hadits, maupun yang tidak disepakati, yakni syar'u man qablana $^{21}$ dan istihsan. ${ }^{22}$ Selain daripada yang telah disebutkan, ada pula landasan asuransi syariah yang bersumber dari piagam Madinah $^{23}$ dan praktek sahabat. $^{24}$

Al-Quran, secara tegas, tidak menyebutkan dalam ayat-ayatnya tentang asuransi. Namun, prinsip-prinsip yang menjadi dasar keberadaan asuransi ada dalam al-Quran, antara lain tolong-menolong dalam kebaikan dan ketakwaan (QS al-Maidah [5]: 2), prinsip kemudahan dan menjauhkan kesukaran (QS al-Baqarah [2]: 185), anjuran melakukan kegiatan sosial dan menafkahkan harta di jalan Allah (QS al-Baqarah [2]: 261), proteksi terhadap bencana, musibah, dan kecelakaan (QS Yusuf [12]: 46-49), mengindari kerugian dan manajemen resiko (QS al-Taghabun [64]: 11), kekuasaan Allah terhadap segala makhluk (QS Luqman [31]: 34), kematian adalah kepastian (QS Ali Imran [3]: 145 dan 185), harta peninggalan bagi ahli waris (QS al-Nisa [4]: 7), dan penanggungan atau penjaminan (QS Ali Imran [3]: 37).

Al-Hadits, seia sekata dengan al-Quran, juga tidak menyebutkan secara eksplisit akan lembaga asuransi dalam Islam. Namun, ada konsep aqilah dalam sebuah hadist riwayat al-Bukhari. Praktek aqilah adalah sebuah tradisi di masyarakat Arab, di mana kerabat dari orang tua laki-laki (aqilah atau ashabah) mempunyai kewajiban menanggung denda (diyat), jika ada salah satu anggota sukunya melakukan pembunuhan terhadap

${ }^{21}$ Yang dimaksud dalil berdasarkan syar'u man qablana adalah praktek aqilah yang terjadi di kalangan masyarakat Arab pra Islam. Pada masa nabi, praktek ini pun tetap diakui dan diakomodir oleh Islam. Lihat penjelasan selanjutnya berkaitan dengan hadist tentang aqilah.

22 Asuransi syariah mengandung unsur kemaslahatan dan kebaikan. Lihat Muhammad Muslehuddin, Insurance and Islamic Law. Penerjemah: Burhan Wirasubrata, Menggugat Asuransi Modern: Mengajukan Suatu Alternatif Baru Dalam Perspektif Hukum Islam. (Jakarta: Lentera, 1999), hlm.31.

${ }^{23}$ Dalam Piagam Madinah disebutkan bahwa keselamatan hidup tawanan dijamin dan adanya lembaga tebusan (diyat) bagi tawanan dari para aqilah sukunya. Lihat Ahmad Sukardja, Piagam Madinah dan Undang-Undang Dasar 1945. (Jakarta: UI-Press, 1995), hlm. 47.

${ }^{24}$ Praktek sahabat berkenaan dengan pembayaran hukuman (ganti rugi) pernah dilaksanakan oleh Umar bin Khattab, khalifah kedua. Umar memerintahkan agar diwan (daftar) saudarasaudara muslim disusun perdistrik. Orang-orang yang namanya tercantum dalam diwan, berhak menerima bantuan dari satu sama lain dan harus menyumbang untuk pembayaran hukuman (ganti rugi) atas pembunuhan (tidak sengaja) yang dilakukan oleh salah satu anggota masyarakat mereka. Praktek ini dianalogikan sebagai asuransi (takaful) dalam masyarakat. Lihat Muhammad Muslehuddin, Insurance and Islamic Law..., hlm. 31. 
anggota suku lain. ${ }^{25}$ Penanggungan bersama oleh aqilah-nya adalah suatu kegiatan yang mempunyai unsur seperti yang berlaku dalam asuransi. ${ }^{26}$ Dalam praktek aqilah ini, ada prinsip saling menanggung (takaful) antar anggota suku di dalam kehidupan masyarakat Arab dan hal ini tidak dilarang oleh nabi.

Hadits lain yang berkaitan dengan prinsip-prinsip asuransi syariah antara lain: hadits tentang anjuran menghilangkan kesulitan seseorang, ${ }^{27}$ hadits tentang anjuran mempersiapkan bekal bagi keturunan, ${ }^{28}$ hadits tentang pertanggungan anak yatim, ${ }^{29}$ dan hadists tentang menghindari resiko. ${ }^{30}$

Dalam hukum positif di Indonesia, asuransi syariah mengacu pada fatwa Dewan Syariah Nasional (DSN) Majelis Ulama Indonesia No. 21/DSN-MUI/X/2001 tentang Pedoman Umum Asuransi Syariah. Namun, fatwa bukanlah undang-undang, keberadaannya tidak mempunyai kekuatan hukum dalam hukum nasional. Agar ketentuan fatwa memiliki kekuatan hukum, maka perlu dibentuk peraturan perundang-undangan yang berkaitan dengan pedoman asuransi syariah. ${ }^{31}$

Adapun peraturan perundang-undangan yang telah dikeluarkan mengenai penyelenggaraan asuransi syariah antara lain ${ }^{32}$ :

a. Keputusan Direktur Jenderal Lembaga Keuangan No. Kep-3607/LK/2004 tentang Pedoman Penghitungan Batas Tingkat Solvabilitas Minimum Bagi Perusahaan Asuransi dan Perusahaan Reasuransi;

b. Peraturan Menteri Keuangan No. 135/PMK.05/2005 tentang Perubahan Atas Keputusan Menteri Keuangan No. 424/KMK.06/2003 tentang Kesehatan Keuangan Perusahaan Asuransi dan Perusahaan Reasuransi;

c. Keputusan Ketua Bapepam dan LK No. Kep-104/BL/2006 tentang Produk Unit Link. Salah satu strategi investasi untuk unit link adalah strategi investasi syariah apabila perusahaan asuransi jiwa melakukan investasi aset subdana seluruhnya pada surat berharga syariah;

${ }^{25}$ Lihat selengkapnya Muhammad bin Ismail al-Bukhari, Shahih al-Bukhari. (Kairo: Dar alHadist, 2000), juz 4, kitab al-diyat, nomor hadist 2910, hlm. 446.

${ }^{26}$ Lihat AM. Hasan Ali, Asuransi dalam Perspektif Hukum Islam..., hlm. 115.

${ }^{27}$ Lihat Muslim bin al-Hajjaj, Shahih al-Muslim. (Kairo: Dar al-Hadist, 1997), juz 4, kitab albirr wa al-shilah wa al-adab, nomor hadist 2580, hlm. 302.

${ }^{28}$ Lihat Muhammad bin Ismail al-Bukhari, Shahih al-Bukhari..., juz 4, kitab al-faraid, nomor hadist 6833, hlm. 384.

${ }^{29}$ Lihat Muhammad bin Ismail al-Bukhari, Shahih al-Bukhari..., juz 4, kitab al-adab, nomor hadist 6005, hlm. 146.

${ }^{30}$ Lihat Abu Isa Muhammad bin Isa al-Tirmizi, Sunan al-Tirmizi. (Kairo: Dar al-Hadist, 2005), juz 4, kitab sifat al-qiyamah wa al-raqaiq wa al-wara', nomor hadist 2517, hlm. 382.

31 Gemala Dewi, Aspek-aspek Hukum dalam Perbankan dan Perasuransian Syariah di Indonesia..., hlm. 142.

${ }^{32}$ Lihat Yeni Salam Barlinti, Kedudukan Fatwa Dewan Syariah Nasional Dalam Sistem Hukum Nasional di Indonesia. (Jakarta: Badan Litbang dan Diklat Kementerian Agama RI, 2010), hlm. 314. 
d. Peraturan Ketua Bapepam dan LK No. PER-02/BL/2008 tentang Pedoman Perhitungan Batas Tingkat Solvabilitas Minimum Bagi Perusahaan Asuransi dan Perusahaan Reasuransi;

e. Peraturan Menteri Keuangan No. 124/KMK.010/2008 tentang Penyelenggaraan Lini Usaha Asuransi Kredit dan Suretyship. Peraturan ini menegaskan bahwa bagi perusahaan asuransi umum syariah dilarang menyelenggarakan lini usaha asuransi kredit dan suretyship, kecuali telah terbit Peraturan Menteri Keuangan yang mengatur mengenai hal ini untuk perusahaan asuransi umum syariah;

f. Peraturan Pemerintah No. 39 Tahun 2008 tentang Perubahan Kedua Atas Peraturan Pemerintah No. 73 Tahun 2002 tentang Penyelenggaraan Usaha Perasuransian. Pengaturan ini mengenai penyelenggaraan usaha perasuransian berdasarkan prinsip syariah untuk perusahaan asuransi dan perusahaan reasuransi, serta unit usaha syariah dari perusahaan asuransi dan perusahaan reasuransi konvensional;

g. Peraturan Pemerintah No. 81 Tahun 2008 tentang Perubahan Ketiga Atas Peraturan Pemerintah No. 73 Tahun 1992 tentang Penyelenggaraan Usaha Perasuransian. Bagi perusahaan asuransi dan perusahaan reasuransi konvensional yang memiliki izin pembukaan kantor cabang syariah, dinyatakan telah memiliki izin pembukaan untuk unit syariah. Penyesuaian terhadap besar modal dalam penghitungan dana jaminan; dan

h. Peraturan Ketua Bapepam dan LK No. PER-02/BL/2009 tentang Pedoman Perhitungan Batas Tingkat Solvabilitas Minimum Bagi Perusahaan Asuransi dan Perusahaan Reasuransi. Mengubah ketentuan jenis kekayaan investasi dan bukan investasi serta penilaian kekayaan investasi dan bukan investasi untuk perusahaan asuransi dan perusahaan reasuransi syariah.

\section{Penutup}

Sejak hadirnya asuransi syariah di Indonesia 18 tahun lalu, perkembangannya cukup pesat. Banyak perusahaan asuransi yang menjalankan prinsip-prinsip syariah. Hal ini membuktikan bahwa asuransi syariah diminati oleh masyarakat luas di Indonesia. Artinya, telah terjadi perubahan sosial dalam masyarakat yang awalnya hanya memanfaatkan jasa asuransi konvensional, kemudian sebagian beralih ke perusahaan asuransi syariah. Apalagi Indonesia adalah negara yang mayoritas penduduknya memeluk agama Islam. Sehingga, peluang asuransi syariah untuk terus berkembang sangat besar.

Di Indonesia, perkembangan asuransi syariah cukup pesat di tengah masyarakat, namun hal ini tidak diimbangi dengan perkembangan hukum. Dalam teori sosiologi hukum dikatakan bahwa perubahan-perubahan sosial 
dan perubahan-perubahan hukum (atau sebaliknya, perubahan-perubahan hukum dan perubahan-perubahan sosial) tidak selalu berlangsung bersamasama. Artinya, pada keadaan-keadaan tertentu, perkembangan hukum mungkin tertinggal oleh perkembangan unsur-unsur lainnya dari masyarakat serta kebudayaannya atau mungkin hal sebaliknya yang terjadi. Apabila terjadi hal yang demikian, maka terjadilah suatu social lag, yaitu suatu keadaan di mana terjadi ketidakseimbangan dalam perkembangan lembagalembaga kemayarakatan yang mengakibatkan terjadinya kepincangankepincangan. ${ }^{33}$

Sebagaimana disebutkan sebelumnya, asuransi syariah belum diakomodir dalam Undang-Undang Nomor 02 Tahun 1992 tentang Usaha Perasuransian. Adapun peraturan perundang-undangan yang telah kami sebutkan sebelumnya antara lain Keputusan Dirjen Lembaga Keuangan No. Kep-3607/LK/2004, PP No. 81 Tahun 2008 tentang Perubahan Ketiga Atas Peraturan Pemerintah No. 73 Tahun 1992 tentang Penyelenggaraan Usaha Perasuransian, dan sebagainya, belum dapat mengakomodir asuransi syariah, aturan-aturan yang ada cenderung hanya mengatur hal-hal teknis dalam industri asuransi syariah. Artinya ada "lubang kosong" yang belum diatur oleh undang-undang. Apalagi fatwa DSN-MUI yang menjadi pedoman tidak termasuk dalam hierarki peraturan perundang-undangan di Indonesia, sehingga tidak mengikat secara hukum.

Undang-Undang Nomor 02 Tahun 1992 tentang Usaha Perasuransian, yang berlaku saat ini baik bagi asuransi konvensional dan asuransi syariah, perlu diamandemen isinya. Menurut Gemala Dewi, perlu adanya pengaturan lebih lanjut yang harus disesuaikan dengan kondisi dan keberadaan asuransi syariah di Indonesia terutama yang berhubungan dengan pembuatan kontrak baku dalam aktivitas perasuransian syariah. Adapun alasan-alasan pentingnya pembuatan kontrak baku antara lain:

1. Istilah-istilah yang berkaitan dengan perasuransian pada umumnya memiliki konotasi langsung yang bersifat khusus bagi praktek perasuransian secara konvensional saja. Hal ini membutuhkan upaya yang cukup berat untuk menyesuaikannya dengan makna yang dimaksud dalam konsep asuransi syariah.

2. Ketentuan mengenai kontrak yang digunakan dalam operasional asuransi konvensional selalu bertumpu pada ketentuan kontrak menurut hukum perdata barat (KUH Perdata). Di lain pihak, akad yang dipakai dalam asuransi syariah harus berdasarkan pada Hukum Perikatan Islam yang tentunya memiliki perbedaan dengan persyaratan kontrak menurut asuransi konvensional. Misalnya saja

\footnotetext{
${ }^{33}$ Soerjono Soekanto, Pokok-pokok Sosiologi Hukum. (Jakarta: RajaGrafindo Persada, 1980), hlm. 115.
} 
perlu ditekankan bahwa kontrak asuransi syariah harus terbebas dari unsur gharar, maisir, dan riba.

3. Fatwa-fatwa Dewan Syariah Nasional (DSN) yang mengacu pada penerapan prinsip asuransi syariah dalam pembuatan kontrak pada aktivitas asuransi syariah belum mempunyai kekuatan hukum yang memadai, mengingat kedudukan DSN yang belum memiliki kedudukan formal di negara kita.

4. Ketentuan lain yang berkaitan dengan konsep dasar asuransi syariah yang belum terakomodir oleh Undang-Undang Nomor 02 Tahun 1992 tentang Usaha Perasuransian, sehingga payung hukum bagi aktivitas asuransi syariah yang berkaitan dengan penerapan akad secara syariah belum ada. $^{34}$

Gagasan untuk melakukan amandemen Undang-Undang Nomor 02 Tahun 1992 tentang Usaha Perasuransian adalah mendesak dan sangat diperlukan. Hal ini untuk menghindari terjadinya social lag di dalam masyarakat, yakni dengan adanya ketimpangan antara perkembangan asuransi syariah yang tidak diimbangi perkembangan hukum. Hal tersebut hanya dapat dicegah dengan hadirnya undang-undang yang mengakomodir perkembangan tersebut.

\section{Daftar Pustaka}

\section{A. Buku}

Al-Bukhari, Muhammad bin Ismail, 2000. Shahih al-Bukhari, Kairo: Dar alHadist.

Ali, AM, Hasan, 2004. Asuransi dalam Perspektif Hukum Islam: Suatu Tinjauan Analisis Historis, Teoritis, dan Praktis, Jakarta: Kencana Prenada Media.

Al-Hajjaj, Muslim bin, 1997. Shahih al-Muslim, Kairo: Dar al-Hadist.

Al-Jazairi, Abu 'Abd al-Rahman 'Abd al-Majid, al-Qawaid al-Fiqhiyyah: al-Mustakhrajat min Kitab I'lam al-Muwaqqi'in, Beirut: Dar Ibnu Qayyim dan Dar Ibnu 'Affan, t.t.

Al-Tirmizi, Abu Isa Muhammad bin Isa, 2005. Sunan al-Tirmizi, Kairo: Dar al-Hadist.

Al-Zuhaili, Wahbah, 1985. al-Fiqh al-Islami wa Adillatuh, Beirut: Dar alFikr.

Antonio, Muhammad Syafi'i, 1994. Asuransi dalam Perspektif Islam, Jakarta: Syarikat Takaful Indonesia.

\footnotetext{
${ }^{34}$ Gemala Dewi, Aspek-aspek Hukum dalam Perbankan dan Perasuransian Syariah di Indonesia ..., hlm. 210.
} 
1994. Prinsip Dasar Operasi Asuransi Takaful dalam Arbitrase Islam di Indonesia, Jakarta: Badan Arbitrase Muamalat Indonesia.

Barlinti, Yeni Salam, 2010. Kedudukan Fatwa Dewan Syariah Nasional Dalam Sistem Hukum Nasional di Indonesia, Jakarta: Badan Litbang dan Diklat Kementerian Agama RI.

Dewi, Gemala, 2007. Aspek-aspek Hukum dalam Perbankan dan Perasuransian Syariah di Indonesia, Jakarta: Kencana Prenada Media.

, dkk., 2007. Hukum Perikatan Islam di Indonesia, Jakarta: Kencana Prenada Media.

Karim, Adiwarman A., 2011. Bank Islam: Analisis Fiqih dan Keuangan, Jakarta: Raja Grafindo Persada.

, 12 Perusahaan Asuransi Syariah akan Beroperasi, Republika edisi Jumat, 07 Maret 2003.

Muslehuddin, Muhammad, 1999. Insurance and Islamic Law, Penerjemah: Burhan Wirasubrata, Menggugat Asuransi Modern: Mengajukan Suatu Alternatif Baru Dalam Perspektif Hukum Islam,Jakarta: Lentera.

Perwataatmadja, Karnaen A., 1996. Membumikan Ekonomi Islam di Indonesia, Depok: Usaha Kami.

Rodinson, Maxime, 1978. Islam and Capitalism, Austin: University of Texas Press.

Sam, M. Ichwan, dkk, (ed.), 2011. Tanya Jawab Seputar Dewan Syariah Nasional Majelis Ulama Indonesia, Jakarta: Sekretariat DSN-MUI.

Soekanto, Soerjono, 1980. Pokok-pokok Sosiologi Hukum, Jakarta: Raja Grafindo Persada.

Sukardja, Ahmad, 1995. Piagam Madinah dan Undang-Undang Dasar 1945, Jakarta: UI-Press.

Sula, Muhammad Syakir, 2004. Asuransi Syariah (Life and General): Konsep dan Sistem Operasional, Jakarta: Gema Insani Press.

Training \& Development Department PT Asuransi Takaful Keluarga, 2002, Modul Basic Training 2002, Jakarta: PT Asuransi Takaful Keluarga.

\section{B. Peraturan Perundang-undangan}

Fatwa Dewan Syariah Nasional No. 21/DSN-MUI/X/2001 tentang Pedoman Umum Asuransi Syariah.

Peraturan Pemerintah No. 81 Tahun 2008 tentang Perubahan Ketiga Atas Peraturan Pemerintah No. 73 Tahun 1992 tentang Penyelenggaraan Usaha Perasuransian.

Undang-Undang Nomor 02 Tahun 1992 tentang Usaha Perasuransian. 